Received May 25, 2016

Revised November 23, 2016

Accepted December 1, 2016

\title{
From Middle Power to Pivot Power? Korea's Strategic Shifts
}

\author{
IAIN WATSON*
}

\begin{abstract}
Korea has been regarded by as a middle power nation. Korea's accession to Group of Twenty (G20) status and membership of the Organisation for Economic Cooperation and Development-Development Assistance Committee (OECD-DAC) were heralded as confirmation of Korea's status as a middle power. Korea's current regional initiative, the Northeast Asia Peace and Cooperation Initiative (NAPCI), represents a shift from middle power to 'pivot' state. The initiatives have potential theoretical implications for explaining Korea's emerging role in the region.
\end{abstract}

Keywords: Middle Power, Pivot, Eurasia, Connectivity

* Associate Professor, Ajou University, Suwon, South Korea;

E-mail: i.watson@hotmail.co.uk

DOI: 10.16934/isr.17.2.201612.1 


\section{INTRODUCTION}

There has been a relatively common view in International Relations that South Korea's (hereafter Korea) foreign policy reflects the role and the behavioral attributes of a generic middle power (Cooper 2014, 2015; Cooper and Mo 2015; John 2015; Snyder 2015a, 2015b, 2015c; Sohn 2012; Sussex 2011). For Robertson (2013), international peer-recognition of Korea as a middle power is also 'a permanent feature of Korea's approach to the outside world.' Here, therefore, there emerge several different approaches regarding the framing of Korea as a middle power. Firstly, that Korea's geographical and structural position in the international (and associated regional) inter-state system of power politics is of a middle power stuck in between larger powers. Secondly, as a result (or not) of this structure, Korea thereby acts with an issue agenda that corresponds to what are commonly regarded in the literature as the generic criteria of middle power behaviour and resource attributes. Thirdly, that Korea is also a middle power that is unique (but ultimately still a middle power) and that Korea is thereby redefining what more widely counts as a middle power for emerging powers. Fourthly, that despite its agenda, behaviour and geographical location, Korea's traditionally understood middle power role is also constructed by domestic political cultural and interests as a form of soft power national status in and of itself. These various conceptual and empirical tensions can also depend on how or whether the international or regional system is understood as being Westphalian, non-Westphalian but Westernbased, or consisting of sets of divergent globally and regionally unique inter-state systems and relations thereof (Kang 2003). In the Asia-Pacific, for instance, hegemonic or emerging powers can be seen as representing either a challenge to (or a de-coupling from) existing hegemonic states in the Westphalian system or as a challenge to the very values, norms and legal expectations of this system itself. For instance, there may be emerging civilisational clashes being manifested as between a Western Westphalian order (within which regionally non-Western states may reinforce) and a non-Westphalian order from which non-Western states may use but de-couple (Womack 2004).

Debates have centred on the issue of determining what does Korea's own economic rise mean for determining the type of middle power is or might become. One view has been that Korea's middle power diplomacy and behaviour mainly follows the trajectory of domestic capitalist and Chaebol based mercantilism that can often put specific economic interests either in line with foreign policy or restrict wider public diplomacy (Kalinowski and Cho 2012; Kim and Gray 2016). From a geopolitical standpoint, one view is that Korea's middle power role and agenda-setting is proactive precisely because its 'high politics' still remains tied to bandwagoning on the US. In this sense Korea is able to concentrate on furthering its role as both a regional and 'global Korea' middle power through a non-high 
politics issue agenda first mover state. This emphasis on defining a middle power as issue setter would tend to shift away from Korea's earlier envisioning of being a middle power as a regional balancer between China and Japan, and as a bridge between China and the US. Yet, with the rise of China and the famed US rebalance it is possible that other strategic choices and scenarios might emerge. Here, a strategic and alternative Korean middle power man-ship might be enabled by bandwagoning on another regional hegemon, or, that an alternative regional understanding of Korea's middlepowerman-ship might be emerging. For Sung-mi $\operatorname{Kim}(2016)$ :

For more than a decade, the concept of "middle power" has been prominent in South Korea's diplomatic narrative, used by successive governments as a framework for their foreign policy vision and strategy. However, South Korea's policy-makers have adopted the concept without fully unravelling its meanings and their ramifications. Furthermore, its use has not been consistent from government to government. Policy-makers, journalists, experts and scholars have all talked about middle-power diplomacy, but the imagery, intentions and policy emphasis associated with the term have varied. This lack of coherence has resulted in analytical confusion, as well as scepticism among policy analysts and academics about the utility of keeping the "middle power" concept.

One sceptical view is that Korea has no choice but to bandwagon on the US and, therefore, Korea's middle power pro-action is always limited to locating issue niches that rely on this configuration of power. Yet this argument also relies on a particular assumption of US strategic continuity which, for some, no longer resembles the new reality of US relations with longstanding allies who are now hedging (Bremmer 2016). This would, if true, beg the question as to whether Korea's middle power approach need not necessarily be constrained by a set of traditional hegemonic options and choices. This shift for Bremmer, is symptomatic a period of uncertainty and strategic hedging, leading to a strategy of pivoting through the use of new configurations of issue networking and the role of strategic positioning in these networks providing a middle power with a leverage other than that based through a positioning based on or in between hegemonic dominance or greater inclusion into multilateral organisations. The paper shows this new environment through Korea's role in the NAPCI. According to Snyder and Woo (2015) this was an initiative where:

The idea of a Northeast Asia Peace and Cooperation Initiative was developed during Park's presidential campaign and has continued since she took office. The goal of the initiative has been to identify and implement steps necessary 
to address what Park calls the "Asian paradox." The paradox refers to the fact that the region leads the world in economic growth, but it has not yet effecttively addressed longstanding security dilemmas and political conflicts that potentially put that growth at risk.

Realist approaches see secondary (or middle power) foreign policy as determined by hegemonic shifts caused by changes in the distribution of power. As Gilpin $(1981,210)$ noted, '(D)isequilibrium replaces equilibrium, and the world moves toward a new round of hegemonic conflict.' For Mearsheimer $(2005,2010$, 2014), secondary powers will bandwagon on the present (or rising) hegemon (or whichever hegemon provides security) due to uncertainty over state intentions and the need for national survival. For Mearsheimer (2015), national survival is based on power and will always out-trump economic issues. For Kenneth Waltz, secondary powers eventually become a bandwagoning part of the wider regional (or global) balancing strategy of the present (or future) hegemonic state in a bi-polar system.

Liberal institutionalism sees middle power behaviour as significant in and of itself. Middle powers are viewed as reliable conference hosts, convenors, managers and trusted facilitators in their relations between states both outside and within an institutional setting. These roles also represent middle power international citizenship attributes. Yet institutions can also be strategically used by middle powers to further national interests and enmesh larger powers. Middle powers reinforce existent institutional rules, norms and values, and yet can also be proactive firstmover states, particularly on non-traditional niche issues. This literature focuses on middle power 'in-between' positioning within a hierarchy of large and small states and associated behavioural characteristics (Shin 2015).

Social constructivism regards national identity and national branding as an independent variable because construction of national identity is impacted by (and defines) national interests (Wendt 1992). These relations might be manifested as contests between economic elites and diplomatic elites over resources and the maintaining of national soft power branding and credibility. As a result, attempts at self-defining Korea as a middle power can potentially mismatch with reality and generate credibility issues. Korean state-led soft power that is used to enhance a particular view of Korean history, territory and identity can have potential unintended 'hard power' consequences.

From a realist perspective, the NAPCI reflects Korea's ongoing bandwagoning on the US and the economic accommodating of China. The first High-level Intergovernmental Meeting of NAPCI was held on October 28, 2014 with the US, China, Japan, Russia, and Mongolia attending as official participants and the UN, the EU, and NATO attending as dialogue partners. The agenda was based on how to complement any existing mechanisms for cooperation (such as the ARF and the EAS), how to encourage the participation of North Korea, how to improve Korea- 
China-Japan relations and how to identify issues of common interest. From a liberal institutionalist perspective, the initiative represents Korea's middle power behavior in facilitating compromise and effective multilateral cooperation in an era of complex interdependence. From a constructivist perspective, the initiative represents the continuing strategies of Korean soft power and identity construction as a middle power.

My argument is that NAPCI represents shifts in regional power distribution and is an early indicator of a hedging strategy by Korea as a pivot state, as identified by Bremmer (2015). Consequently, NAPCI is aimed at engaging not just niche issues but leverage based on defining the site and nature of multiple issue connections as sets of networks. In this respect, the notion of a pivot state unlocks some of the key assumptions of middle power approaches regarding issue connection, Korea's role and behaviour in emerging forums and what have been termed minilateral organisations, as well as less an emphasis on distinguishing a hierarchy between demarcated regional and global strategies.

First, the paper will outline the main IR perspectives that explain the role and behaviour of middle powers. Secondly, the paper will identify why and how Korea is regarded as a middle power within each of these perspectives. The paper will then place the initiative into these framework expectations. Thirdly, the paper will discuss why and how Korea is understood as a pivot state. To do this the paper will outline Korea's NAPCI and discuss how these initiatives can also be placed into a pivot power context.

\section{REALISM AND MIDDLE POWERS}

Scott Snyder (2015d) notes that the US rebalance is not just about countering a rising power (China) but about 'inputting' resources into the region. For Snyder (2015d), this means an opportunity in redefining the definition of middle powers as not located 'in the middle' (between the US/China or geographical location) but on their 'capacity to connect' to 'hedge against uncertainty.' The view here is that any lessons learnt from the experiences of the Cold War no longer work and that there is, in effect, a 'blank slate' (Snyder 2015d). Bremmer (2012a, 2012b, 2014) has noted that certain middle power/income states are becoming more strategically flexible and resilient. This means they are reducing overreliance on hegemonic states and instead courting 'like-minded' clusters of states but, and crucially, without endangering formal alliances. As a result, defining the nature and type of 'likeminded' and 'peer recognition' is becoming a crucial aspect of the construction of state identity by diplomats and academics, and probably explains why there is also so much interest in Korea regarding the use of soft power and public diplomacy.

Bremmer calls these states pivot states. However, the term pivot is not in any way referring to Mackinder's rather pompous and expansionist thesis (1904) or the 
more recent US pivot (Clinton 2011). Pivot states, Bremmer (2012a, 2012b) notes, can increasingly reflect how middle power countries are now hedging because they do not want 'to get crushed in the nutcracker of U.S.-China competition.' On the other hand, there is a view that domestic Korean elites are unnecessarily fabricating (or exaggerating) the limits of Seoul's choices in another attempt to enrich the idea of Korean uniqueness (and therefore to gain regional leverage over Japan). However, this slippery slope and potentially counter-productive strategy can potentially sew a false distinction and confusion between a desire for power and peerrecognition through national victimhood, and the narrative of uniqueness. This can provoke a set of counter-productive policies given how surrounding states might negatively react to what is perceived as opportunism and uncertainty in reading Korea's intentions and telegraphed emotions over Japan.

For realists, middle or secondary powers have limited choices given the role of hegemonic states. Hegemonic power rests upon dominance in a leading technological or economic sector, backed by military power. When there is balance of power or one hegemonic state then middle powers have limited choices and decide to bandwagon. However, at a time of hegemonic shift then the opportunity for changing alliances may appear. For Gilpin (1981) a rising hegemon will challenge the existing hegemon and will create a new institutional system with its own (but not necessarily new) set of ideals and preferences. Yet identifying the form of transition process can be problematic and can lead to debates over identifying to what extent (and in what form) traces of the previous hegemonic system (or former hegemon's agenda within a system) remain. This is determining whether a hegemonic state rise is (or will be) occurring within the existing regional system, and reinforcing or challenging the previous hegemon's system or not. It is also possible that a rising hegemon may challenge the system's norms and values (Westphalia) but accommodating or coopting these values without necessarily transitioning to a new order. For instance, the rise of China has led to potential strategic and value-based confrontations with the US but whilst recognising the Westphalian legal and normative values of national sovereignty. Yet this recognition of Westphalian legal and normative values is respected as China is also seen to reestablish a non-Westphalian hierarchical order in the region.

These issues also impact the responses and choices of and for the smaller regional states. Gilpin (1981) argues that the more decisive a victory of the rising hegemon then the more stable the new system will be. Jervis $(1978,187)$ also noted that 'change in the international system is described by a series of events where an established hegemon has its power undermined by differential growth rates among states.' Snidal $(1985,579)$ argued that 'the presence of a single, strongly dominant actor in international politics leads to collectively desirable outcomes for all states in the international system.' During an 'uneven process of great-power balancing, a rising power can compel a secondary state to accommodate it' (Ross 2006, 367). For Mearsheimer, 'the ideal situation for any great 
power is to be the hegemon in the system, because its survival then would almost be guaranteed' (Mearsheimer 2001, 61). This is because, Mearsheimer (2001) argued, states can never truly be sure of other states' intentions so that it is only through power maximisation that states can ensure their survival. The defensive realist view is that states try to maximise their share of world power whilst understanding that the system will punish them if the states unsettle the balance of power. For Waltz, states are not power maximisers but instead they are security maximizers.

In a unipolar regional system the middle power will bandwagon the hegemon (Holbraad 1971). However, relations with the regional hegemon, if placed in a wider multilateral or global setting, might offer greater leverage for the middle power. This occurs if the regional hegemon becomes enmeshed in costly regional and multilateral commitments and the middle power has access to a greater array of allies. In a bipolar regional or global system, middle powers may resort to bandwagoning or hedging (Ross 2006). If bi-polarity is balanced then a middle power may be potentially able to take strategic advantage of hegemonic balance/stability to pursue other non-traditional or comparative advantage agendas/allies. In a multipolar system, middle powers participate more in the central system by joining other states to balance hegemons or devote attention to sub-systemic or regional concerns (Holbraad 1971). Hegemons may in turn wish to maintain a dominant position through lower institutional costs by using middle powers in neither dominating nor abandoning middle powers.

\section{LIBERALS AND MIDDLE POWERS}

For liberal institutionalists, emphasis is placed more on 'demand' and cooperation for international regimes from all states. Yet liberal institutionalism also assumes that states are still primarily concerned with zero-sum and absolute gains (Mearsheimer 1995, 28, ft 93). Even writers such as Robert Keohane and Joseph Nye still take a conventional view of the international system and power, albeit displayed and used in different forms and ways. In this respect, middle powers are particularly keen to exact an image and agenda of the 'peacemaker' or the 'workhorse' that facilitates and encourages reasonableness and cooperation. Middle powers can play a part in such regimes by legitimating the principles, norms, values, rules and expectations of these institutions. The behavioural approach focuses on middle power roles such as 'good citizen', issue trendsetter, institutional mediator and multilateral partner facilitator or bridge state. Middle power delimitation refers to the territorial, economic, cultural, or political context in which the middle power is embedded. This role deployment concerns the question of whether middle power behaviour and leadership claims are recognised. Middle power endowment refers to impact over other states (Shim and Flamm 2012). Middle power states may be (or regarded as) regional relative powers but are 
internationally marginalised. However, the states may be proactive internationally but perceived as relatively minor in the regional near-abroad. Middle powers may also be prone to promote an internationalist agenda globally but can also become increasingly and militarily assertive in their near abroad regional neighbourhood (Kim 2014).

\section{SOCIAL CONSTRUCTIVISTS AND MIDDLE POWERS}

Social constructivists provide an approach with unique insights into the issue of middle powers. For Wendt $(1992,417)$ :

A constructivist analysis of cooperation, in contrast, would concentrate on how the expectations produced by behavior affect identities and interests. The process of creating institutions is one of internalizing new understandings of self and other, of acquiring new role identities, not just of creating external constraints on the behavior of exogenously constituted actors.

States as agents act toward designated objects of security and actors on the basis of the meanings that diplomats and actors give to the referent objects. This means that 'Identities are the basis of interests' insofar as '(A)ctors do not have a "portfolio" of interests that they carry around independent of social context; instead, they define their interests in the process of defining situation' (Wendt 1992, 398). For Wendt (1992), a specific kind of national identity formation also occurs in an anarchical system because processes of identity-formation are fundamentally concerned with (although not necessarily determined by) the preservation or security of the state. This inevitably brings in the issues of determining the causal relations and intensity of relations between processes of agency and structure. As a result, issues of national branding strategies and national identity construction from domestic institutions become fundamental to how a state fashions itself in terms of culture, experience and history. This, in turn, impacts the kinds of states that are regarded as 'peers' with peer recognition becoming a key aspect of identity construction. Such processes are particularly significant for those states that do not have huge resources of traditional 'hard power' indicators.

\section{CONCEPTUAL INTERPRETATIONS OF KOREA AS A MIDDLE POWER}

Korea can either be regarded as fitting a generic middle power role or as having its own middle power uniqueness that is self-defined by elites and soft power in the sense of a Goffman 'looking glass self' ego that is constantly under construction from domestic and foreign audiences. This suggests a constant need for reassurance or a 'what do they think of us' that is coupled with a narrative of uniqueness. Tow 
and Limaye (2016) recently pointed out that the post-WWII San Francisco regional model has been seen as a regional architecture, regional community or an association of states. Such systems can be defined as being threat driven or goal driven. Tow and Limaye (2016) also argue that the post-Cold War era was also assumed to witness US alliance dissolution and a shift to a more East Asian regional collective security multilateralism. There is now assumed to be not only a choice between hegemonic states but on the kind of issues involved such as trade/ economics (China) and security (US). However, seeing this as a fixed and perennial dichotomy would be to 'push the point too far' (Tow and Limaye 2016, 21).

China and the US are seen as representing a wider continental (Eurasia) and maritime (Asia-Pacific) balancing (Choi 2013; Eurasia 2015; Kim 2015; MOFA 2015; Stroken 2014). The Economist Intelligence Unit (2016) regards any China 'hard-landing' economic collapse as a geopolitical risk. A Chinese demise has been longingly charted by some (Chang 2015). The fear of Chinese collapse narrative is now seemingly replacing the previous 'fear of rise' narrative (Breslin 2009, 817). The main danger for regional stability, as Mearsheimer once noted, is when hegemonic states become unsure of one anothers' intentions (Callahan 2015). For Mearsheimer, the US is increasingly an 'offshore balancer' against the rise of yet another Eurasian hegemon. Mearsheimer argues that China's past peaceful behavior is an 'unreliable indicator' of future behavior (Mearsheimer 2010, 385). For Mearsheimer, the US (and most of China's neighbors) will attempt to contain China whilst less powerful states' may increase trade with China to incorporate China into regional and international organisations. Mearsheimer (2015) argues that Korea has been given a choice of hegemon and cannot go on hedging and but will at some point have 'to choose at some point' and that this choice is real. To deal with this 'final' choice of which hegemon to bandwagon Korea has been delinking issues to maintain its autonomy and flexibility.

As a result, Mishra (2015) notes that 'it would interesting to see what choice Korea makes, as it would determine Korea's approach to regional politics in the future as well as its own place in its emerging dynamics.' For some, Korea's national interest has traditionally been best-served when the region is in balance (Rozman 2007). This is when the security-orientated triangle of Korea-US-Japan is balanced with the economic-based trilateral Korea-China-Japan (Snyder 2015a). With the US rebalance, Korea will be expected to provide financial and technological resources (Mearsheimer 2014). Traditionally it has been the liberals who have pursued better relations with China (interpreted as more autonomy or equality with or from the US) whilst the conservatives have coveted the maritime alliances with the US and Japan.

During the Park, Chung-hee era (1961-1979) Korea was self-located in the Pacific Rim narrative. The term Northeast Asia was used for the Northern communist states (Kim 2008). In the post-Cold War era, President Roh, Tae-won (1988-1993) promoted the Consultative Conference for Peace in Northeast Asia 
which was sub-regional specific and included Korea, North Korea, US, Japan, China and Russia. President Kim, Young-sam (1993-1998) initiated the 'North East Asia Security Dialogue.' During this time the term East Asia referred to the regional cooperation scheme anchored in ASEAN+3 (and excluded the US, Canada, Australia and New Zealand). China was not seen as a major regional hegemon, whilst Korea was self-perceived as the more developed nation. The Roh, Moo-hyun administration (2003-2008) promoted the 'North East Asian Cooperation Initiative' as an opportunity for Korea in the post-1997 crisis era to become an effective independent middle power regional bridge (Ko 2006). The liberal Roh, Moo-hyun administration (2003-2008) asserted the need for maintaining alliance ties with the US but through what it regarded as the need for greater equality in the relationship. This was the shift for a 'rising' Korea as a proactive and more neutral middle power and as a gateway to the region. For Shin (2015) 'Roh unpacked the concept in the regional context, focusing more on regional security and inter-Korean relations' (Shin 2015, 2).

The Lee (2008-2013) administration argued that a strengthened US-Korean alliance would allow for regional 'cooperation through strength' with China. The Global Korea initiative (Korea 2008, 8) had been based on the view that '(T)he concept of national interest is becoming increasingly wedded to global public welfare, and a states' external legitimacy and leadership are thus predicated on its ability to combine the national interest with the global public welfare.' This is because it was put forward that a states' capability in a niche issue area is not necessarily reflective of its overall potential, nor is the magnitude of state power synonymous with the ability to solve every problem. Shin (2015) recently noted that 'the swings and vacillations in the ROK's geopolitical posture, i.e. from "going regional" to "going global," are indicative of the inherent challenges it confronts in identifying and defining an optimum middle power role' (Shin 2015, 20). Kim, Sung-han has noted:

South Korea has thereby aimed to harmonize its own interests with those of its counterpart countries and the world community, as well as to undertake various efforts to address global issues. Its two recent incarnations-as a developing nation and now as a developed country with an advanced economy -will inform South Korea as it takes on a greater role in global affairs. As South Korea executes its middle-power diplomacy, it does so within the framework of the G20 (Kim 2013).

For Kim, Korea's 'middle-power diplomacy' is creating an issue-driven, informal, and flexible dialogue mechanism. For Kim (2013), Korea is also projecting its national brand to developing countries and as an issue based or 'niche' first mover and middle power roles in the Organisation for Economic Cooperation and Development (OECD), as an Arctic Council observer state and in the G20. During 
the Lee presidency, Korea's role in the G20 was termed 'bridge', which was a role that was seen as a way of bringing together developed and developing nations. This also includes a greater engagement as convenor and host of international meetings and institutions, with opportunities to present Korea to the outside world and thus raise its international profile. This opened a paradoxical scenario that Korea acted more as an emerging middle power globally than in its own region. According to John $(2015,44)$ the prevailing discourse of seonjinguk (like a Western advanced nation):

is dynamic and its assumptions and representations of Korea's historical transformation have been affected by various factors at the national and global level. This fluidity is also manifest in the different governmental slogans adopted by successive Korean governments in their efforts to utilize the authority of the seonjinguk ideal. Three key slogans can be identified: (1) guendaewa (modernization), during authoritarian regimes from the early 1960s till the mid-1980s; (2) segyehwa during the 1990s; and (3) seonjinwa (achieving advancement) since the late 2000s.

President Lee's (2008-2013) regional 'New Asia Initiative' was, as a result, also embedded in the Global Korea strategy yet Lee had refrained 'from bundling all countries in an undistinguished regional mass' (Fumugalli 2016, 43). As John $(2015,39)$ notes ' $(T)$ he Lee government was the first to adopt the middle power rhetoric officially into Korean foreign policy, and Global Korea was the platform to launch Korea's middle power diplomacy.' As John $(2015,54)$ also notes 'President Lee Myung-bak marked the reassertion of the discourse of seonjinguk in Korean identity and nation branding, particularly in international affairs. Global Korea was the discursive site where the assertion of middle power identity and the project of achieving seonjinguk status seemingly converged. Middle power identity provided a clear template for shaping Korea's diplomatic practice and international role, under the unifying slogan of Global Korea.' However, the '(P)erennial lack of acknowledgment from peer nations' problematically 'appears to be the main obstacle to considering South Korea as a regional power' (Shim and Flamm 2012, 5). As Bong (2016) notes the issue of constructing Korea as having a middle power identity has potentially become a key factor in determining Korea's alliance priorities and regional self-location as either a Eurasian continental (China-Russia) or Asia-Pacific 'seafaring' nation (US-Russia).

\section{NAPCI AS A MIDDLE POWER INITIATIVE}

If placed in a traditional middle power model then the case can be made that NAPCI is either representing a regional bridge, as a regional balancing role, or is a continuation of the global Korea extra-regional strategy. It would be expected, as a 
continuing middle power, for Korea to continue its bandwagoning on the US rebalance (although the US Pacific pivot seemed to be more orientated towards the South Pacific) and within this scenario making its choices from this set of options in the context of a continuing effort at global multilateralism and prioritising a set of issue niches. I will argue that Korea's 'pivot hedging' may indeed look like bandwagoning but that the NAPCI potentially represents an alternative way in which Korea is dealing with and reformulating its regional security issues. In other words, Korea's middle power leverage is now based on issue-network positioning and issue connecting ability rather than on geography, positioning with hegemonic states, middle power resource metrics or inclusion into regional or global institutions. NAPCI is a supplementary to these processes and I am suggesting that this itself (and given the wider context) might indicate a shift in middle power strategy and potentially a challenge to the very concept of what a middle power 'is.' According to the Korean government (NAPCI 2015, 1):

The Northeast Asia Peace and Cooperation Initiative (NAPCI) is a key element of the Trustpolitik pursued by the Park Geun-hye administration. It is a futureoriented effort by the ROK Government to replace a structure of conflict and discord in the region with an order of dialogue and cooperation. The initiative focuses not on immediately establishing a body for multilateral cooperation but rather it places more emphasis on the process of constantly fostering small yet meaningful forms of cooperation. It aims to gradually encourage a change in perception and attitudes of countries of the region with a view to eventually developing a shared understanding with regard to multilateral security cooperation.

NAPCI takes a bottom-up approach seeking to induce the consolidation of political will on the part of governments on soft security issues which are 'relatively less sensitive and do not represent a significant burden for the participating governments' (NAPCI 2015, 10). The government claims it has relied 'too much on the conventional toolbox' with 'the narrow range of either bilateral means or realpolitik' and thus with 'little hope for Northeast Asia in breaking out of the traditional security dilemma.' Realists see NAPCI merely as just another way of bandwagoning and pleasing the US-Korea alliance as means of avoiding decisions and choices between hegemons through a narrative of inclusivity. NAPCI is also regarded as merely a way for the US to in effect softly co-opt China. A further realist view is that China may in turn just use NAPCI as a means to create further fissures in relations between the US and Japan and as a springboard for creating an alternative 'security architecture' in the region. A further concern is that the 'inclusion' of North Korea into NAPCI will allow North Korea's nuclear program de facto legitimacy. This is because North Korea's nuclear program can be discussed in terms of nuclear safety (rather than on nuclear disarmament) or will not be 
discussed at all. In the context of Korea's 'trustpolitik' an issue raised might be whether trust is based on a 'cards on the table' or through taking controversial issues off the table so as not to undermine 'harmony' with a simultaneous narrowing and broadening of issues to achieve this. For realists, the Seoul Process is further perceived as an extension of the US-Korean alliance rather than as an independent South Korean-led initiative. However, even despite objectives that coincide with the interests of the US-Korean alliance, this does not necessarily mean a causal relationship. However, Snyder and Woo (2015) do point out that the US-Korean alliance does indirectly provide a platform for independent South Korean efforts to promote its interests as a 'middle power.' South Korean interests are mutually reinforcing and deeply compatible with US interests. However, this argument makes sense only if the US-Korea alliance is relatively stable. In this respect NAPCI indicates not only the increasing linkages between issues but also the redefining of the type and nature of these issues. The emphasis on North Asia is also specific yet indicates not simply a return to traditional regional parameters but if placed in the wider context of Korea's regional strategies, a potential formulation of the new demarcations of North Asia and Eurasia. In this respect NAPCI potentially indicates an effort that is no longer based on the 'insulation' of regional politics by fixed boundaries, nor, a strategy that reinforces a fixed spatial hierarchy or a transitional mindset such as 'moving from regional to global.' Instead the very understandings of what actually counts as regional and global is emerging. For Snyder and Woo (2015) Korea aims to define its nascent leadership role within East Asia even if it acts 'in concert' with the US to reinforce shared objectives. NAPCI (2015) states that:

The Government has in the past proposed measures for the establishment of a multilateral security mechanism in the Northeast Asian region through such initiatives as the "Consultative Conference for Peace in Northeast Asia" and "Northeast Asia Security Dialogue." However, these efforts did not materialise as planned and were not able to move beyond the level of a concept. The reason that momentum for such initiatives was lost is that they placed a focus on addressing hard security issues in which cooperation is difficult, and were aimed at institutionalizing inter-governmental dialogue in a short space of time.

Furthermore, the cooperation on soft security issues in the pursuit of NAPCI will ultimately help to ease tensions and contribute to the restoring of mutual trust which is the key in addressing hard security issues (NAPCI 2015, 29). There are the already-established region-wide institutions such as the East Asia Summit, the Association of Southeast Asian Nations, or ASEAN, Regional Forum (ARF), and the ASEAN Defense Ministerial Meeting Plus (ADMM+) so there is a concern that a sub-regional mechanism with membership solely from Northeast Asia, is unnecessarily duplicative and unnecessarily segregates the region from these more 
established mechanisms. As Snyder and Woo (2015) point out,

President Park is attempting to draw Washington into various forms of regional cooperation in which the United States has an interest. The region has already developed institutional cooperation on non-traditional security issues through two primary processes that excluded the United States: the establishment of the Trilateral Coordination Secretariat among China, Japan, and South Korea and the development of the Chiangmai Initiative that enabled currency swaps to minimize the contagion effects of a renewed financial crisis in the region. But South Korea's proposal recognizes that there are additional functional issues of concern in the region in which the United States has an interest and a role to play, including counterterrorism, nuclear safety, and energy security. NAPCI may serve as a particularly apt platform on which to build capacity for these functional issues.

\section{NEW CONTEXT AND STRATEGIES: REINTERPRETING NAPCI}

Bush (2012) has noted that Beijing's rise is significant in determining the future pattern of big power relations (Cookson 2015; Tiezzi 2015). US allies such as Korea are responding positively to China's new economic institutions (Yale 2015) whilst managing the US-based liberal order (Keck 2014; Panda 2015; Sunnylands 2015; Vershbow 2014). Dollar (2015) has argued that economic excess capacity in China is the reason for China's new regional infrastructure initiatives. For Dollar (2015) '(M)any major economies in Asia, such as Australia, Singapore, South Korea, and Vietnam want to be part of both Chinese initiatives (the AIIB and the "One Belt, One Road") and the American effort to reduce trade barriers.' According to $\operatorname{Kim}(2014,4)$ :

we can understand the concept of structure as the patterns of dynamic transactions at the level of relationship among actors, without reducing the concept of structure to the level of a unit. In other words, we conceptualize structure, not as a kind of fixed entity reduced to actors' internal properties or attributes, but as a social relationship among, or across, actors. Compared to the neorealist macroscopic concept of structure, this concept in network perspective understands structure at the meso-scopic level. The meso-scopic concept of structure portrays the dynamics between an actor's choice and structural changes.

Bremmer (2012a) has noted that 'some countries are better positioned than others to prosper in this decentralized global order' so that the ability to pivot among multiple political and commercial partners, can ensure that a country is 'blessed with resilience.' This means that pivot nations are able to maintain partnerships 
and previous alliances without becoming overreliant. Bremmer (2012b) also noted that 'the winners and losers of the next generation will be determined not by the rubrics of the moment but by how well and often they are able to pivot.'

For instance, when two states are connected by a set of social relations a tie is formed. The strength of a tie varies with the frequency, duration, intensity, and reciprocal quality of that relation (Hafner-Burton et al. 2009). Leverage of connector states is engaged through sets of flexible institutional mechanisms that can allow for the exchange of tangible (information and services) and intangible (social support and authority) goods. An actor's ability to introduce new norms, manipulate symbols and influence political outcomes impacts on states' leverage. Those actors aiming for a higher network centrality and transmission flow in the network can withhold (rather than constrain) social benefits to others. More nodes and more information that is flowing and passing through these nodes (density) as network enmeshments (rather than autonomy) can give a state or actor greater leverage (Hafner-Burton et al. 2009). Korea seeks tangible outcomes derived from cooperation on specific projects as a way of building 'topdown momentum based on a bottom-up process', South Korea envisions a voluntary and process-driven approach that attempts to build political will to overcome mutual mistrust through the experiences derived from issue-based cooperation. The Park administration also has spoken of the need to eventually shift attention from easy to difficult issues, and the desire to contribute to the strengthening of regional and international norms. Thus, NAPCI (and Korea's role within NAPCI) can be understood as being positioned as in-between the US-led network and a China-led network and within NAPCI these networks are also being connected. Korean Foreign Minister Yun, Byung-se (2014) argued that:

our strategy is to move this regional cooperation beyond Northeast Asia to Eurasia. My government's Eurasia Initiative envisions enhancing connectivity on several fronts, including transport and energy networks as well as peopleto-people and cultural exchanges. We see some potential in the on-going Rajin-Hassan logistics projects involving South and North Korea and Russia, as well as several Silk Road projects pursued by neighbouring countries (Yun 2014).

Crucially, the Foreign Minister (Yun 2014) further stated that 'Some people suggest that Korea is tilting too much towards China or that Korea is sandwiched between the US and China' but that 'These observations are as superficial as they are glib, in that they view Korea's relationship with the two giants as a zero-sum game' as 'this isn't a matter of pick and choose.' Whilst the hegemonic countries may be competing over who has authority (or leadership) in the region, these states are not contesting the basic rules of the system of openness and multilateralism. 
Snyder (2015) argues that the NAPCI now begins to fill an emerging structural gap created by and between the US rebalance and a China on hold. International seminars have been held (Korea-NATO NAPCI Seminar on July 9, 2014). The Joint Korea-EU Seminar was held on September 18-19 2014. In 2015 there were joint seminars with NATO, the EU, the OSCE, and ASEAN. The Korean Deputy Foreign Minister has also stated that 'NAPCI is open to North Korea' and 'that we plan to continue to work to increase the benefits of cooperation and have North Korea voluntarily join the initiative' (Cho 2015). It was argued that previous subregional policies of engagement were based on a principled approach which resulted in consistency but lacked flexibility. This, it was argued, generated long term inconsistency as reality changed. As Snyder and Woo $(2015,5)$ point out 'South Korea has an inherent interest in building effective standards for cooperation within the region.' According to Jackson (2015) 'NAPCI responds to a clear need in Northeast Asia' because 'not only does it attempt to fill the institutional gap Northeast Asia suffers from, but it also attempts to create more positive patterns of interaction to help balance out the negative ones that have dominated for decades.' NAPCI takes its approach and objectives on what it terms 'a realistic understanding of reality.'

\section{NETWORK ORGANISATION AND COOPERATION}

NAPCI can be seen as situated at a hub of issue networks which are connecting and flowing through Korea's own position within NAPCI. This is a potential shift from a middle power that is based on the role of facilitator, convenor or bridge. Issue priorities can constantly change, so even if the state has a few material resources the point is that others' power can potentially only be realised through final connections by a network state. This makes these flexible states increasingly pivotal, and they may never know when they will be needed or when network connections might require it. This approach moves from previous issues of institutional inclusion and exclusion. This has been an issue for middle powers and previous strategic dilemmas of increasing status and having their 'seats at the high table' which might be to reinforce or reject institutional norms or expectations, or to socialise or be more radical. Traditional liberal institutional approaches to middle powers have long regarded the problem of cooperation, prisoners' dilemmas costs of defection and the maintaining of autonomy as an opportunity cost. Instead, alliances can be understood as emerging clusters of like-minded states rather than formal alliances with similar values and expectations. For instance, Tow and Limaye (2016) identify the importance of what Moises Naim has termed 'minilateral' institutions based on a small number of large and small states, and where leverage is seen to be based on controlling network connectivity and information flows. NAPCI's positioning both lies within the wider network gaps between the regional 
large powers whilst simultaneously including (and networking) these powers. In contrast to previous Korean initiatives NAPCI is not based on high politics (and top down responses) or low politics (through grandiose aspirations.) Instead, NAPCI is seen to be opening avenues beyond these 'false' choices. Therefore, issues of free-riding and first mover disadvantages, as well as cooperation based on 'homogeneity', are potentially bypassed. For instance, NAPCI $(2015,27-28)$ states that given 'the diversity between the countries of Northeast Asia in political, economic and cultural terms, and considering the continuing tensions over historical issues, it is necessary to take a step by step and long-term approach in pursuing multilateral security dialogue in the region.' NAPCI (2015) also recognizes that there is a need to lay the basis for mutual trust and to ensure a sense of ownership. This is done in two main ways. According to NAPCI $(2015,9)$ :

The initiative focuses not on immediately establishing a body for multilateral cooperation but rather it places more emphasis on the process of constantly fostering small yet meaningful forms of cooperation. It aims to gradually encourage a change in perception and attitudes of countries of the region with a view to eventually developing a shared understanding with regard to multilateral security cooperation.

For Korea, NAPCI is therefore being designed as a flexible multilateral framework with emphasis on co-ownership and inclusivity to lower the barriers for participation. This allows a minimum of political risk. NAPCI also aspires to build trust in the region specifically by addressing 'functional issues such as nuclear energy and non-proliferation, cooperative development assistance, and regional economic treaties' (Snyder and Woo 2015, 1). NAPCI 'is not pursued in accordance with a prearranged timeline with a view to the immediate establishment of a specific organisation for multilateral cooperation. Rather, the initiative focuses on how to accumulate small but meaningful practices of cooperation' $(2015,7)$. For Yun (2014) NAPCI 'is a potential roadmap for implementing trustpolitik at the regional level and transforming the existing structure of mistrust and confrontation into one of trust and cooperation' (Yun 2013, 2015). NAPCI $(2015,14)$ seeks:

to foster cooperation first among countries that are willing to participate, in fields relatively easy to embark on cooperation, and at a pace which is acceptable to all participating countries. NAPCI seeks, by securing recognition of the value of the multilateral cooperation in the region and by promoting a sense of mutual understanding, to transform the existing structure of mistrust and confrontation in the region into one of reconciliation and cooperation.

Accordingly, 'NAPCI hopes to secure the participation of all countries in the 
Northeast Asian region, including North Korea, in the mechanism for dialogue and cooperation. With a view to expanding cross-regional partnerships, it will seek to strengthen ties on particular issues with other regional institutions such as in Southeast Asia and Europe' (NAPCI 2015, 17). NAPCI seeks 'to create a synergy effect' between intergovernmental cooperation and experts in the private sector (MOFA 2015, 17). This means that 'Rather than a particular country leading the process, it would be more desirable and meaningful for all countries with ideas for cooperation to feel a sense of ownership in the pursuit of cooperation. In this context, the ROK is ready to assume the role of a facilitator for regional cooperation' (NAPCI 2015, 19). For Snyder and Woo $(2015,9)$ 'it may be more diplomatically palatable in some cases for China, South Korea, and Japan to begin functional cooperation efforts with a focus on Southeast Asia' rather than to start the process in Northeast Asia (Kwon 2014; Lee 2014). For McCoy (2015), NAPCI also fills a gap that has been created by a track record of previous attempts at regional cooperation that have led to nowhere because:

External factors aren't working either. Diplomacy, sanctions and long-running talks have had little, if any, effect. That brings us to South Korean President Park Geun-hye's Northeast Asia Peace and Cooperation Initiative (NAPCI). It is a process that begins with cooperation on small matters that leads to building trust. The more cooperation there is, the more trust accumulates. From trust eventually comes peace. It should not be difficult to understand that with peace, prosperity has a chance.

According to McCoy (2015) the idea of having many and increasing operational or tactical approaches and networks has not been tried before in this context. This means connecting and complementing the existing institutional mechanisms (but not necessarily values). For Deputy Foreign Minister Cho (2013) this is not aimed at 'hastily' achieving tangible results, nor to preclude top down when or if information is required or is 'at the right setting.' Van Jackson (2015) has noted that 'If one is primarily concerned with preserving the status quo ante in the region and globally then new initiatives of any kind are an inherent risk.' This brings in the question determining what is meant by status quo and order and such a view from Jackson (2015) maybe a common rhetorical device to imply that NAPCI does (or will) have influence. Yet the notion of 'defining' influence or impact is itself a result of shared information and 'like-minded' consensus. For Jackson (2015), NAPCI is potentially a 'high impact response' to regional uncertainty. As a result, middle power opportunities are based more on network positioning and increasing network connections rather than on middle power autonomy. For both McCoy (2015) and Snyder (2015, 2015d) speaking at the 2015 IFANS meeting, NAPCI's value is with brokering connections between non-state actors who can help solve 
(yet might be vulnerable to) transnational threats on the one hand.

For Shin (2015), national self-locating is a key aspect of middle power branding. However, the notion of locating is supplemented (or supplanted) by the redefining of the 'world' and the notion of location itself. Foreign Minister Yun, Byung-se has for instance used the term 'neighbour' in his various speeches to describe the US's legitimate place in the region as a Pacific state, whilst simultaneously re-narrating the region from a Korean perspective through NAPCI as both Asia-Pacific and as Eurasian. This redefining strategy complements the wider regional and national identity reconstructions emerging from China and the US regarding Eurasia and Trans-Pacific approaches. For instance, in NAPCI (2015) documents, Korea is being self-represented and self-located as the hinge or pivot nation in the region. With NAPCI, the US and China are being placed into a mutual Pacific axis, along with the heartland of Central Asia which includes Russia and China. In Korea, the Eurasia Initiative is placed within the context of infrastructure and free-trade (Park 2013a, 2013b, 2013c). The Korean based Eurasia Initiative accommodates a variety of sub-national actors and local urban initiatives such the Korean Governors Conference of the East Sea Rim's Local Governments. The initiative is reconstructing perceptions of regional spaces not as 'blocs' by connecting sub-regions and city networks. President Park (2013a) had noted that the Korean peninsula is 'the far eastern starting point on the path across the Eurasian continent' and the 'easternmost pillar of the Eurasian economic sphere' as 'a gateway connecting Eurasia to the Pacific.' The Eurasia Initiative is to connect the Eastern end of Eurasia with the Northern Sea Route (with China and East Siberia), to connect the EU to ASEAN networks in the South, and with NAFTA networks across the Pacific. President Park (2013a) also stated 'It would also be of great significance to build a Eurasian energy network' to 'serve as a catalyst in creating a Eurasian economic bloc involving landlocked nations in Eurasia.' As President Park (2013a) put it, 'the creation of such as New Eurasia is not simply an ideal and a dream but a viable goal to achieve.' This means that if domestic efforts 'to promote a creative economy were joined together, it would create enormous synergy and help the Eurasian region emerge as a growth engine of the world economy' (Park 2013a).

\section{CONCLUSION}

The paper has argued that the traditional expectations of Korea's role and behaviour from IR middle power theory can increasingly be complemented or supplemented. This is because of shifts in regional geopolitics as well as approaches to strategic partnering through networks. These shifts are reflected by the new initiatives. It is this emergent shift in network positioning that might cause potential re-evaluations of Korea's role and middle power identity. The paper has 
argued that network states do not necessarily act within fixed spatial dimensions of the region but construct and represent a continual process of connecting, disconnecting and reconnecting networks which redefine and recast the location and identity of the region.

\section{REFERENCES}

Bong, Youngshik David. 2016. "The U.S-South Korea Alliance: Local, Regional and Global Dimensions." Asian Politics and Policy 8(1): 39-49.

Bremmer, Ian. 2012a. "Welcome to the G-zero Era." The Huffington Post, http:// www.huffingtonpost.com/ian-bremmer/international-trade-pivot-states_b_15 15310.html

Bremmer, Ian. 2012b. "The Future Belongs to the Flexible." The Wall Street Jour nal http://www.wsj.com/articles/SB10001424052702304811304577365990 370899520

Bremmer, Ian. 2014. "Winners and Losers in a G-zero World." Diplomatic Courier, http://www.diplomaticourier.com/ian-bremmer-winners-and-losers-in-a-g-ze ro-world/

Bremmer, Ian. 2016. "Comments, CNN Global Public Square." $13^{\text {th }}$ November.

Breslin, Shaun. 2009. "Understanding China's Regional Rise: Interpretations, Identities and Implications." International Affairs 85: 4 817-835.

Bush, Richard C III. 2012. "The Response of China's Neighbors to the US Pivot to Asia." Brookings http://www.brookings.edu/research/speeches/2012/01/31us-pivot-bush

Callahan, Bill. 2015. "Mearsheimer versus Nye on the Rise of China." The Diplomat, http://thediplomat.com/2015/07/mearsheimer-vs-nye-on-the-rise-ofchinal

Chang, Gordon C. 2015. "Will 2016 Bring the Collapse of China's Economy." The National Interest, http://nationalinterest.org/feature/will-2016-bring-thecollapse-chinas-economy-14753

Choi, He-suk. 2013. "Park Seeks Eurasia Initiative to Build Energy Logistics Link." The Korea Herald, October 18.

Cho, Tae Yul. 2013. "Deputy Foreign Minister Remarks." http://www.mofa.go.kr/ webmodule/htsboard/template/read/engreadboard.jsp?typeID=12\&boardid=4 726\&seqno $=313071$

Clinton, Hilary. 2011. "America's Pacific Century.” http://www.state.gov/secre tary/20092013clinton/rm/2011/11/176999.htm

Cookson, John Richard. 2015. "Obama Puts the Asia Pivot on Pause." The National Interest, http://nationalinterest.org/feature/obama-puts-the-asia-pivotpause-14049

Cooper, Andrew. 2014. “Middle Powers Squeezed Out or Adaptive?” Public Di- 
plomacy Magazine, http://publicdiplomacymagazine.com/middle-powers-squ eezed-out-or-adaptive/

Cooper, Andrew. 2015. "Recalibrating Middle Power Diplomacy: The Changing Soft Power Brands of Republic of Korea and Canada in Comparative Perspective." East Asia Institute, February 23, http://www.eai.or.kr/data/bbs/kor report/2015022313102417.pdf

Cooper, Andrew. and Jongyno Mo. 2015. "Middle Powers Can Punch Above Their Weight." Wall Street Journal, http://www.wsj.com/articles/SB100014 24052970203716204577015480229858806

Corrado, Jonathan. 2015. "NAPCI: The Answer to Strategic Impatience with North Korea." http://www.dailynk.com/english/read.php?cataId=nk02501\&num=13510

Dollar, David. 2015. "China's Rise as a Regional and Global Power: The AIIB and the "One Belt One Road." Brookings Institute http://www.brookings. edu/research/papers/2015/07/china-regional-global-power-dollar

Economist Intelligence Unit. 2016. "Debt is Rising Unsustainably in China." http://country.eiu.com/article.aspx?articleid $=1464034930 \&$ Country $=$ China\& topic $=$ Economy\&subtopic $=$ Forecast

Eurasia. 2013. "Eurasia Initiative.” http://www.nuac.go.kr/english/sub04/view01. jsp?numm $=36$

Fumagalli, Matteo. 2016. "Growing Inter-Asian Connections: Links, Rivalries, and Challenges in South Korean-Central Asian Relations." Journal of Eurasian Studies 7(1): 39-48.

Gilpin, Robert. 1981. War and Change in International Politics. Cambridge: Cambridge University Press.

Hafner-Burton, Emilie, Miles M. Kahler, and Montgomery, A. H. 2009. "Network Analysis for International Relations." International Organization 63(3): 559592.

Holbraad, Carsten. 1971. "The Role of Middle Powers." Cooperation and Conflict 6(1): 77-90.

Jackson, Van. 2015 "Can South Korea fix North East Asia's Cooperation Deficit." The Diplomat, http://thediplomat.com/2015/09/can-south-korea-fix-northeastasias-cooperation-deficit/

Jervis, Robert. 1978. "Cooperation under the Security Dilemma." World Politics, 30(2): 167-214.

John, Jojin V. 2015. "Globalization, National Identity and Foreign Policy: Understanding Global Korea." Copenhagen Journal of Asian Studies 33(2): 38-57.

Jordaan, Eduard. 2003. "The concept of a middle power in international relations: distinguishing between emerging and traditional middle powers." Politikon: South African Journal of Political Studies 30(1): 165-181.

Kalinowski, Thomas and Cho. 2012. "Korea's Search for a Global Role Between Hard Economic Interests and Soft Power." European Journal of Develo- 
pment Research 24(2): 242-260.

Kang, David. 2003. "Getting Asia Wrong: The Need for New Analytical Frameworks." International Security 27(4).

Keck, Zachary. 2013. "The Three Faces of Park's Trustpolitik." The Diplomat, May 9. http://thediplomat.com/2013/05/the-three-faces-of-parks-trustpolitik/

Keck, Zachary. 2014. "Under US Pressure Major Countries Snub China's New Regional Bank." The Diplomat, October 23. http://thediplomat.com/2014/10/ under-us-pressure-major-countries-snub-chinas-new-regional-bank/

Kim, Keeseok. 2008. "How Has Korea Imagined its Region." Korean Journal of International Studies 6(1): 73-110.

Kim, Sangbae. 2014. "Roles of Middle Powers in East Asia: A Korean Perspective." East Asia Institute, http://www.eai.or.kr/type/panelView.asp?bytag $=\mathrm{p} \&$ code $=$ eng report\&idx $=12726 \&$ page

Kim, Soyeun and Kevin Gray. 2016. "Overseas Development Aid as Spatial Fix? Examining South Korea's Africa policy." Third World Quarterly 37(4): 649664.

Kim, Sung-han. 2013. "Global Governance and Middle Powers: South Korea's Role in the G20." http://www.cfr.org/south-korea/global-governance-middlepowers-south-koreas-role-g20/p30062

Kim, Sung-mi. 2016. "South Korea's Middle Power Diplomacy: Changes and Challenges." https://www.chathamhouse.org/sites/files/chathamhouse/public ations/research/2016-06-22-south-korea-middle-power-kim.pdf

Kim, Taehwan. 2015. "Beyond Geopolitics: South Korea's Eurasia Initiative as a New Nordpolitik." The Asan Forum, http://www.theasanforum.org/beyondgeopolitics-south-koreas-eurasia-initiative-as-a-newnordpolitik/

Korea. 2008. "Diplomatic White Paper." October 27, 2008, Ministry of Foreign Affairs and Trade, http://www.mofat.go.kr/english/political/whitepaper/index. jsp

Kwon, Yong. 2014. "South Korea's Eurasian Ambitions." The Diplomat, http://the diplomat.com/2014/08/south-koreas-eurasia-ambitions/

Lee, Sang-hyun. 2014. "NAPCI: A Vision Toward Sustainable Peace and Cooperation in Northeast Asia." The Asan Forum, http://www.theasanforum. org/the-northeast-asia-peace-and-cooperation-initiative-napci-a-vision-towardsustainable-peace-and-cooperation-in-northeast-asia/

Mackinder, H. J. 1904. "The Geographical Pivot of History." The Geographical Journal 23(4): 421-437.

McCoy, Robert. 2015. "A Remedy for Head in the Sand Thinking on North Korea." https://www.nknews.org/2015/11/a-remedy-for-head-in-the-sand-thinking-onn-korea/

Mearsheimer, John J. 1995. "The False Promise of International Institutions." International Security 19(3): 5-49 
Mearsheimer, John J. 2001. The Tragedy of Great Power Politics. New York: Norton.

Mearsheimer, John J. 2005. "The Rise of China Will Not Be Peaceful at All." The Australian, November 18.

Mearsheimer, John J. 2010. "The Gathering Storm: China's Challenge to US Power in Asia." The Chinese Journal of International Politics 3(4): 381-396.

Mearsheimer, John J. 2014. "Middle Powers in Asia: Limits of Realism.” http:// www. lowyinterpreter.org/post/2014/07/09/Middle-power-Asia-realism.aspx

Mearsheimer, John J. 2015. "IFANS Conference on Global Affairs.” https://www. youtube.com/watch?v=oBrApXuwVKI

Mishra, Sandip Kumar. 2015. "South Korea: US THAAD or Chinese AIIB." http://www.ipcs.org/article/china/south-korea-us-thaad-or-chinese-aiib-4857. $\underline{\mathrm{html}}$

MOFA. 2015. "North East Asia Peace and Cooperation Initiative." Ministry of Foreign Affairs, March 10, http://www.mofa.go.kr/ENG/North Asia/res/eng 2015 0310.pdf

NAPCI. 2015. "Northeast Asia Peace and Cooperation Initiative 2015." http:// www.mofa.go.kr/ENG/North_Asia/res/eng 2015 0310.pdf.

Panda, Ankit. 2015. "South Korea Joins the AIIB." The Diplomat, March 28. http://thediplomat.com/2015/03/south-korea-joins-the-aiib/

Park, Geun-hye. 2013a. "Speech to US Congress." Yonhap News, May 8, http:// english.yonhapnews.co.kr/national/2013/05/08/4/0301000000AEN20130508 010800315F.HTML

Park, Geun-hye. 2013b. "Remarks International Conference: Global Cooperation in the Era of Eurasia." http://www.korea.net/Government/Briefing-Room/ Presidential-Speeches/view?articleId=114334\&pageIndex $=3$

Park, Geun-hye. 2013c. "Dresden Speech." http://english.yonhapnews.co.kr/full/ 2014/03/28/40/1200000000AEN20140328008000315F.html

Robertson, Jeffrey. 2013. "S Korea Takes Growing Role as Middle Power." http:// www.koreaherald.com/view.php?ud=20130417000968

Ross, Robert. 2006. "Balance of Power Politics and the Rise of China: Accommodation and Balancing in East Asia." Security Studies 15(3): 355-395.

Rozman, Gilbert. 2007. "South Korea and Sino-Japanese rivalry: A Middle Power's Options within the East Asian Core Triangle." The Pacific Review 20(2): 197-220.

Shim, David and Patrick Flamm. 2012. "Rising South Korea: Minor Power or a Regional Player.” https://giga.hamburg/en/system/files/publications/wp200 shim-flamm.pdf

Shin, Soon-ok. 2015. "South Korea's Elusive Middlepowermanship: Regional or Global Player?” The Pacific Review DOI: 10.1080/09512748.2015.1013494.

Snidal, Duncan. 1985. "The Limits of Hegemonic Stability Theory." International 
Organization 39(4): 579-614.

Snyder, Scott. 2015a. "Middle Power Korea." http:/www.cfr.org/asia-and-paci fic/middle-power-korea/p36623?cid=otr-marketing-use-middle power korea Snyder, S. 2015b. "US Rebalancing Strategy and South Korea's Middle Power Diplomacy." East Asia Institute, March 6, http://www.eai.or.kr/data/bbs/ eng report/2015030618362920.pdf

Snyder, Scott. 2015c. "How South Korea's NAPCI Could Complement the Rebalance." Forbes, http://www.forbes.com/sites/scottasnyder/2015/10/01/howsouth-koreas-napci-could-complement-the-rebalance-to-asia/\#2715e4857a0b $5134 \mathrm{e} 00 \mathrm{~d} 3 \mathrm{a} 30$

Snyder, Scott. 2015d. "IFANS 2015." https://www.youtube.com/watch?v=aV01Y 3vAKjI

Snyder, Scott and Jung-yeop Woo. 2015. "The U.S. Rebalance and the Seoul Process How to Align U.S. and ROK Visions for Cooperation in East Asia." Council on Foreign Relations, http://www.cfr.org/asia-and-pacific/us-rebalan ce-seoul-process-align-us-rok-visions-cooperation-east-asia/p35926

Sohn, Yul. 2012. "Searching for a New Identity: Public Diplomacy Challenges of South Korea as a Middle Power." http://www.kf.or.kr/file/pdf/\%EC\%86\% 90\%EC $\% 97 \%$ B4- $\%$ EB $\%$ B0\%9C $\%$ ED $\% 91 \% 9 \mathrm{C} \% \mathrm{~EB} \% \mathrm{AC} \% \mathrm{~B} 8 . \mathrm{pdf}$

Strokan, Sergey. 2014. "South Korea: Knocking at Eurasian Door." Russia Today, http:/www.rt.com/op-edge/168116-south-korea-eurasian-door/

Sung-Bin, Ko. 2006. "South Korea's Search for an Independent Foreign Policy." Journal of Contemporary Asia 36 (2): 258-273.

Sunnylands. 2015. "Declaration." http://www.asean.org/joint-statement-of-the-ase an-u-s-special-leaders-summit-sunnylands-declaration/

Sussex, M. 2011. "The Impotence of Being Earnest: Avoiding the Pitfalls of 'Creative' Middle Power Diplomacy." Australian Review of International Affairs 65(5): 545-562.

Tiezzi, Shannon. 2015. "With Trilateral Summit, China-Japan-Korea Cooperation 'Completely Restored.'” The Diplomat, http://hediplomat.com/2015/11/withtrilateral-summit-china-japan-korea-cooperation-completely-restored/

Tow, William T. and Satu Limaye. 2016. "What's China Got To Do With It: U.S. Alliances and Partnerships in the Asia-Pacific." Asian Politics and Policy 8 (1): 7-26.

Vershbow, Alexander. 2014. "NAPCI Solving the Asia Paradox." http://www.nato. int/cps/en/natohq/opinions 114190.htm

Womack, Brantly. 2004. "Asymmetry Theory and China's Concept of Multipolarity." Journal of Contemporary China, 13(39): 351-366.

Yale, William. 2015. “China’s Maritime Silk Road Gamble.” The Diplomat, April 22. http://thediplomat.com/2015/04/chinas-maritime-silk-road-gamble/ Yun, Byung-se. 2013. “Trustpolitik A New Framework for South Korea’s Foreign 
Policy." Global Asia, https://www.globalasia.org/wp-content/uploads/2013/09/ 462.pdf

Yun, Byung-se. 2014. "Peace and Cooperation in North East Asia." Chatham House, https://www.chathamhouse.org/sites/files/chathamhouse/field/field_do cument/20141006NortheastAsiaYun.pdf

Yun, Byung-se. 2015. “Addis Speech.” http://www.un.org/esa/ffd/wp-content/uplo ads/sites/2/2015/07/Korea.pdf 